\title{
Origin and significance of Late Cretaceous bioevents: Examples from the Cenomanian
}

\author{
Markus Wilmsen \\ Acta Palaeontologica Polonica 57 (4), 2012: 759-771 doi: http://dx.doi.org/10.4202/app.2011.0044
}

Palaeontological events, documented by widespread beds or thin intervals of strata with either unusual ("exotic") or acmes of common faunal elements are a characteristic feature of Upper Cretaceous epicontinental shelf sediments in NW Europe. Their importance in stratigraphic calibration has early been recognized and these "bioevents" are widely used as correlation tools. Furthermore, it appears that there is a genetic link between sequence and event stratigraphy as most of the "classic" bioevents developed during specific intervals of a $3^{\text {rd }}$-order depositional sequence. Early transgressive bioevents (ETBs) are subdivided into two subtypes, i.e., the lag and migration subtype. The lag subtype corresponds to the transgressive surface and develops in response to winnowing and relative enrichment of robust biogenic hardparts. Taphonomic alteration and time-averaging are important features. The migration subtype is related to the disappearance of physical or ecological barriers that triggered faunal migrations. Despite their onlapping character,most ETBs are quasi-isochronous, and their preservation potential is usually high. Thus, they are very useful stratigraphicmarkers.Maximum flooding bioevents (MFBs) represent autochthonous biogenic concentrations with relatively low shell densities. They are related to habitat stability and ecospace expansion, and develop by population blooms of taxa well adapted to the special maximum flooding conditions of thewide epicontinental shelf ofNWEurope (e.g., low food availability). CenomanianMFBs ofNWEurope are not time-averaged and may comprise stratigraphically more expanded intervals with gradational lower and upper boundaries. Their often wide palaeogeographic extent associated with very high chances of preservation results in an excellent inter-basinal correlation potential. Late highstand bioevents (LHBs) are local to regional shell concentrations deposited as a result of increasing winnowing of fines and reworking by storms, currents and waves during late highstands. LHBs usually consist of paucior even monospecific skeletal concentrations with a high degree of fragmentation. Simple shell beds related to a single (storm) event, and composite (multiple-event) shell beds are recognized. LHBs share some features of ETBs, but lack of time-averaging, are laterally restricted and have low preservation potential. Thus, their importance in interbasinal correlation is poor. The time scales of Cenomanian bioevents range through several orders ofmagnitude (hours-days in LHB storm event concentrations to $~ 100 \mathrm{kyr}$ in MFBs). In terms of position within sequences, the three bioevent types correspond to shell concentrations recognized in Mesozoic-Cenozoic formations around the world. Shell beds with similar positions within cycles as well as comparable sedimentologic and taphonomic characteristics have also been described from high-frequency sequences and 
parasequences, suggesting that the formational processes of shell beds operate in base-level controlled sedimentary cycles of different hierarchies (i.e., $3^{\text {rd }}-$ up to $7^{\text {th }}-$ order).

Key words: Palaeontological events, correlation, sequence stratigraphy, Cretaceous, Europe.

Markus Wilmsen [markus.wilmsen@senckenberg.de], Senckenberg Naturhistorische Sammlungen Dresden, Museum für Mineralogie und Geologie, Sektion Paläozoologie, Königsbrücker Landstr. 159, D - 01109 Dresden, Germany.

This is an open-access article distributed under the terms of the Creative Commons Attribution License (for details please see creativecommons.org), which permits unrestricted use, distribution, and reproduction in any medium, provided the original author and source are credited.

Fof Full text $(875.9 \mathrm{kB})$ 